\title{
Benzo[b]thiophenesulphonamide I, I-dioxide derivatives inhibit tNOX activity in a redox state-dependent manner
}

\author{
I Encío', DJ Morré2, R Villar ${ }^{3}$, MJ Gil ${ }^{3}$ and V Martínez-Merino*,3 \\ 'Department of Health Sciences, Universidad Pública de Navarra, Avda. Barañain, 31008 Pamplona, Spain; ${ }^{2}$ Department of Medicinal Chemistry and \\ Molecular Pharmacology, Purdue University, West Lafayette, IN 47907, USA; ${ }^{3}$ Department of Applied Chemistry, Universidad Pública de Navarra, \\ Campus Arrosadía, 31006 Pamplona, Spain
}

Benzo[b]thiophenesulphonamide I,I-dioxide (BTS) derivatives are strong cytotoxic agents that induce reactive oxygen species (ROS) overproduction and apoptosis in tumour cells. Although the precise origin of BTS-induced ROS is not known, a clear correlation between their cytotoxic effect and ability to inhibit a tumour-associated NADH oxidase (tNOX) activity of the plasma membrane has been described. To analyse the putative implication of tNOX in BTS-induced ROS generation, in this work we have synthesised and tested a new BTS derivative, the 6-[N-(2-phenylethyl)]benzo[b]thiophenesulphonamide I, I-dioxide. According to its high lipophilicity, this compound showed a strong cytotoxic activity against a panel of six human tumour cell lines, including two human leukaemia (K-562 and CCRF-CEM) and four human solid tumours (HT-29, HTB54, HeLa and MEL-AC). We also tested the ability of this compound to inhibit the tNOX activity and we found an absolute dependence of this inhibition on the redox state of the tNOX: while under reducing conditions, that is, $100 \mathrm{mM} \mathrm{GSH}$, the drug inhibits strongly the NOX activity with an $\mathrm{EC}_{50}$ of about $0.1 \mathrm{nM}$, under oxidising conditions, there is no effect of the drug or just a slight stimulation of activity.

British Journal of Cancer (2005) 92, 690-695. doi:I0.1038/sj.bjc.6602383 www.bjcancer.com

Published online I February 2005

(c) 2005 Cancer Research UK

Keywords: benzo[b]thiophenesulphonamides; antineoplasic drugs; ECTO-NOX; tumour-associated NADH oxidase; redox state

Benzo $[b]$ thiophenesulphonamide 1,1-dioxide (BTS) derivatives have been reported as a new class of potential antineoplastic agents (Martínez-Merino et al, 2000). These compounds, which were synthesised and analysed in in vitro antitumour assays on the basis of theoretic structure-activity COMFA studies of sulphonylureas (Martínez-Merino et al, 1995; Gil et al, 1999), induce in human leukaemia CCRF-CEM cells a typical process of apoptosis that includes cell shrinkage, phosphatidylserine translocation to the cell surface, mitochondrial dysfunction, caspase activation, chromatin condensation and internucleosomal DNA degradation (Alonso et al, 2003). CCRF-CEM cells start to accumulate reactive oxygen species (ROS) within minutes after BTS addition, and these molecules are essential mediators required for the induction of cytochrome 3 mitochondrial release, caspase- 3 activation and cell death, as revealed by the fact that these events are prevented by treatment with $\mathrm{N}$-acetyl-cysteine (Alonso et al, 2003). Although the precise origin of BTS-induced ROS is not known, a clear correlation between their cytotoxic effect and ability to inhibit an NADH oxidase (NOX) activity found in the plasma membrane and conditioned culture medium of CCRF-CEM cells has been described (Alonso et al, 2001).

*Correspondence: Professor V Martínez-Merino;

E-mail: merino@unavarra.es

Received 26 July 2004; revised 9 December 2004; accepted 9 December 2004; published online I February 2005
ECTO-NOX are cell surface-associated and growth-related protein oxidases that exhibit two different activities, protein disulphide-thiol interchange and hydroquinone (or NADH) oxidation, that alternate to yield oscillatory patterns (Morré and Morré, 2003). Two forms of ECTO-NOX have been detected in sera of cancer patients (Wang et al, 2003): a widely distributed constitutive NOX (CNOX) of the mammalian cell surface that has a period length of $24 \mathrm{~min}$ (Sedlak et al, 2001) and is resistant to inhibition by quinone site inhibitors (Chueh et al, 2002a) like the vainilloid capsaicin or the antitumour sulphonylurea $N$-4-(methylphenylsulphonyl)- $N^{\prime}$-(4-chlorophenyl)urea (LY181984), and a tumour-associated NOX (tNOX) with a period length of $22 \mathrm{~min}$ (Chueh et al, 2002a) that is inhibited by capsaicin (Morré et al, 1997a) or LY181984 (Morré and Reust, 1997b) and is low or absent from sera of individuals not diagnosed as having cancer (Morré et al, 1997a). The tNOX protein is also specifically inhibited in HeLa and human mammary adenocarcinoma cells by (-)epigallocatechin-3-gallate (EGCg) (Morré et al, 2000), the principal catechin of green tea; EGCg also inhibited growth of transformed cells in culture. Since this action appears to result from an effect on regulation of cell cycle progression and induction of apoptosis (Ahmad et al, 1997, 2000, 2002; Gupta et al, 2000) rather than from an unspecific antioxidant function (Salucci et al, 2002), tNOX protein has been proposed as the molecular target on cancer cells to explain their specific inhibition of growth by EGCg (Morré et al, 2000).

The putative implication of tNOX in BTS-induced ROS generation and the fact that some enzymes related with ROS 
control such as the glutathione reductase and the glutathione $S$-transferase present a hydrophobic pocket near their active site (Karplus and Schulz, 1989; Chern et al, 2000) led us to synthesise and analyse new derivatives of the benzo[b]thiophene 1,1-dioxide carrying hydrophobic substituents of different length and grade of flexibility on the sulphonamide group and, in some cases, a clear correlation between the lipophilicity $(\log P)$ and the cytotoxic effect of these compounds was observed (Villar et al, 2004). Here we describe the synthesis and cytotoxic activity of 6-[ $N$-(2-phenylethyl)]benzo[ $b]$ thiophenesulphonamide 1,1-dioxide (BTS-2), a new BTS derivative with increased flexibility, high lipophilicity $(\log P=2.82)$ and a predicted low toxicity for its putative metabolites, and we show its ability to specifically inhibit the tNOX activity and the absolute dependence of this inhibition on the redox state of the tNOX.

\section{MATERIALS AND METHODS}

\section{Chemistry}

Benzo $[b]$ thiophenesulphonamide 1,1-dioxide (BTS-1) was prepared as previously described (Martínez-Merino et al, 2000).

The synthesis of BTS- 2 was carried out by the usual methods described for the synthesis of sulphonamide derivatives (Villar et al, 2004), that is, through the treatment of the sulphonyl chloride derivative with ammonia or amines (Scheme 1). The chlorosulphonyl derivative was obtained from the 6-aminobenzo[b]thiophene 1,1-dioxide by the Meerwein's method (Meerwein et al, 1957) (treatment of diazonium salts with sulphonyl chloride in the presence of cuprous chloride), and then treated with phenetylamine to give the BTS-2 $(28.1 \%$ yield $)$. The previous amine derivative was produced by reduction of 6-nitrobenzo $[b]$ thiophene 1,1-dioxide, and the last one was synthesised according to procedures previously published (Challenger and Clapham, 1948) ( $60 \%$ yield). The oxidation of benzo[ $b]$ thiophene was carried out with $30 \%$ hydrogen peroxide.

\section{Cell culture}

American Type Culture Collection (ATCC, Manassas, VA) or European Collection of Cell Cultures (ECACC, Porton Down, Salisbury, UK) provided human tumour cell lines. Six cell lines were used: two human leukaemia (K-562 and CCRF-CEM) and four human solid tumours, one colon carcinoma (HT-29), one lung carcinoma (HTB54), one cervix epitheloid carcinoma (HeLa) and one melanoma (MEL-AC). MEL-AC cells were kindly provided by Dr Natalia López-Moratalla (Universidad de Navarra, Pamplona, Spain). Human lung fibroblasts (HLFs) were kindly provided by Dr Markus Nabholzs (ISREC, Epalinges, Switzerland). Cells were grown in RPMI 1640 medium (Life Technologies, Barcelona, Spain) supplemented with $10 \%$ fetal calf serum, $2 \mathrm{~mm}$ L-glutamine,
$100 \mathrm{U} \mathrm{ml}^{-1}$ penicillin, $100 \mu \mathrm{g} \mathrm{ml}^{-1}$ streptomycin and $10 \mathrm{~mm}$ HEPES buffer ( $\mathrm{pH}$ 7.4).

\section{Cytotoxicity assay}

The cytotoxic effect of each substance was tested at five different doses between 0.01 and $100 \mu \mathrm{m}$. Each substance was initially dissolved in DMSO at a concentration of $0.1 \mathrm{M}$, and serial dilutions were prepared using culture medium. The plates with cells from the different lines, to which media containing the substance under test were added, were incubated for $72 \mathrm{~h}$ at $37^{\circ} \mathrm{C}$ in a humidified atmosphere containing $5 \% \mathrm{CO}_{2}$. Cytotoxicity was then determined by a colorimetric microassay based on the use of MTT (Mosmann, 1983). Results are expressed as $\mathrm{GI}_{50}$, concentration that reduced by $50 \%$ the growth of treated cells with respect to untreated controls.

\section{Protein isolation and determination}

Cell membrane NOX activity (Cellex) was released in soluble form from HeLa cells (whole cells) as previously described (Del CastilloOlivares et al, 1998).

Proteins were determined by the bicinchoninic acid/copper assay (Smith et al, 1985) obtained from Pierce using bovine serum albumin as standard.

\section{NADH oxidase activity measurement}

NADH oxidase activity was determined as the disappearance of $\mathrm{NADH}$ at $340 \mathrm{~nm}$ in a reaction mixture containing $25 \mathrm{~mm}$ Tris-Mes buffer ( $\mathrm{pH}$ 7.2), $1 \mathrm{~mm} \mathrm{KCN}$ to inhibit any potential mitochondrial oxidase activity and $150 \mu \mathrm{M} \mathrm{NADH}$ at $37^{\circ} \mathrm{C}$ and continuous stirring (Wang et al, 2003). Assays were initiated by addition of NADH. Absorbance was recorded for $1 \mathrm{~min}$ after adding $\mathrm{NADH}$ and a millimolar extinction coefficient of 6.22 was used to determine specific activity.

\section{RESULTS}

The cytotoxic activity of BTS-1 and BTS-2 (Figure 1) was tested against a panel of human tumour cell lines, including cervix epitheloid carcinoma (HeLa), lymphocytic leukaemia (CCRFCEM), myelocytic leukaemia (K-562), melanoma (MEL-AC),
A<smiles>NS(=O)(=O)c1ccc2c(c1)S(=O)(=O)C=C2</smiles>

B

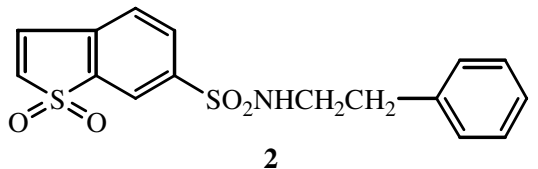

Figure I Structure of BTS used in this work.

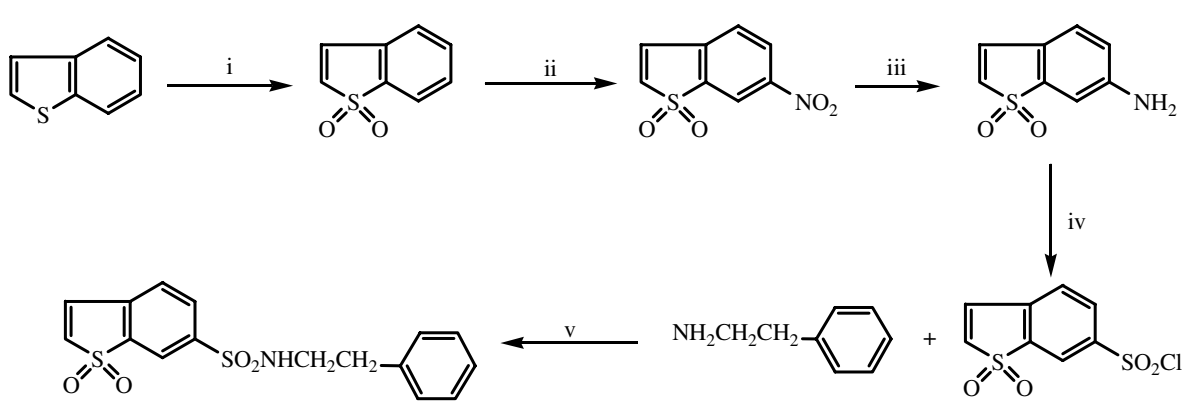

Scheme I i: Acetic acid, $\mathrm{H}_{2} \mathrm{O}_{2} 30 \%\left(v^{-1}\right)$, reflux, 30 min; ii: nitric acid I00\%; iii: $\mathrm{Fe} / \mathrm{ClNH}_{4}$, ethyl alcohol/water $50 \%$; iv: $\mathrm{NaNO}$, $\mathrm{HCl}(\mathrm{ac})$; $\mathrm{SO} / \mathrm{CuCl}$, acetic acid; v: $\mathrm{CH}_{2} \mathrm{Cl}_{2}$; triethylamine. 
Table I Cytotoxic activities ( $\mathrm{G}_{50}, \mu \mathrm{M}$ inhibition of cell growth) against tumor cell lines and lipophilicity

\begin{tabular}{lcccccccc}
\hline Compound & HeLa & CCRF-CEM & K-562 & MEL-AC & HT-29 & HTB-54 & HLF & log P \\
\hline BTS-1 & 2.2 & 2.86 & 29.41 & 7.14 & 8.55 & 5.89 & 5.04 \\
BTS-2 & 0.24 & 0.1 & 0.07 & 0.81 & 2.52 & -0.03 \\
Dx & 0.02 & 0.03 & 0.02 & 0.01 & ND & ND & 0.04 & 2.82 \\
\hline
\end{tabular}

Dx: doxorubicin; ND: not determined.

A
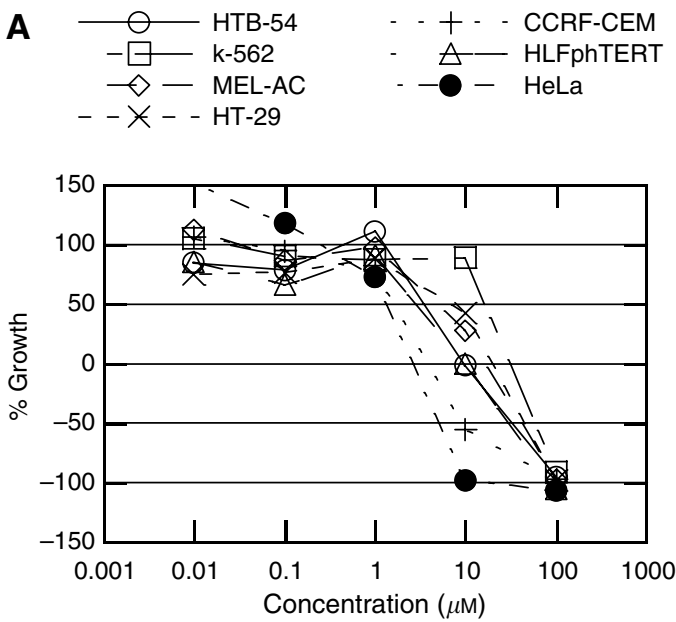

B
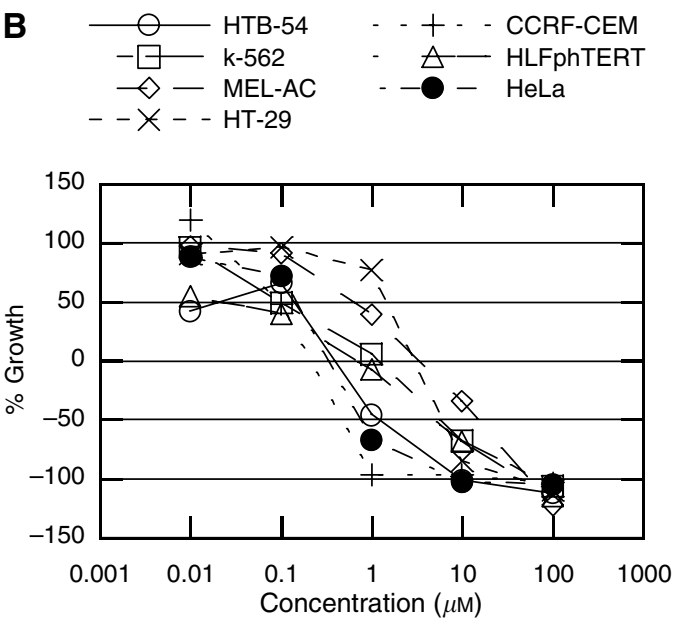

Figure 2 Determination of the cytotoxic effect of $(\mathbf{A})$ BTS-I and (B) BTS-2. Cells were incubated in the presence of every compound at the indicated concentration for $72 \mathrm{~h}$. Cytotoxicity was then determined by a colorimetric microassay based on the use of MTT (Mosmann, 1983). Values represent means \pm s.d. derived from three independent experiments each performed in quadruplicate.

human colon carcinoma (HT-29) and lung carcinoma (HTB-54), and also against normal HLFs growing in culture. Cells were grown in RPMI 1640 medium (Life Technologies) supplemented with $10 \%$ fetal calf serum, $2 \mathrm{~mm} \mathrm{L-glutamine,} 100 \mathrm{u} \mathrm{ml}^{-1}$ penicillin, $100 \mu \mathrm{g} \mathrm{ml}^{-1}$ streptomycin and $10 \mathrm{~mm}$ HEPES buffer ( $\mathrm{pH}$ 7.4). The cytotoxic effect of each substance was tested at five different doses between 0.01 and $100 \mu \mathrm{M}$. The plates with cells from the different lines, to which media containing the substance under test were added, were incubated for 3 days and cell survival was then determined by an MTT-based colorimetric assay (Mosmann, 1983). Results are expressed as $\mathrm{GI}_{50}$, concentration that reduced by $50 \%$ the growth of treated cells with respect to untreated controls. As shown in Table 1, growth of every cell line was clearly affected by the tested compounds, and is worth noting that according to its higher lipophilicity, BTS-2 was more cytotoxic against each one of the tested cell lines than the lead compound (BTS-1). Moreover, activity of BTS-2 was in the same order of magnitude as commercial doxorubicin against K-562 tumour cells and normal lung fibroblasts growing in culture. Figure 2 shows curves with the original data from which the $\mathrm{GI}_{50}$ values for BTS-1 and BTS-2 were calculated.

It has been previously shown that BTS-1 and some related diarylsulphonylureas (DSU) are able to inhibit a tumour cellspecific NOX activity present in the membrane of CCRF-CEM cells (Alonso et al, 2001). As we had said before, until now tNOX activity is the only cell target proposed to explain the specific inhibition of growth of cancer cells induced by the antitumour sulphonylurea LY181984 (Morré et al, 1995a,b) and the green tea catechin EGCg (Morré et al, 2000). Since BTS-2 was designed on the basis of experimental results obtained with BTS-1 and other BTS that are structurally related with DSU, we decided to further analyse the action of BTS-2 on tNOX activity. For these purpose, we performed standard NOX assays using either a preparation released at pH 5 from HeLa cells obtained from Cellex Biosciences

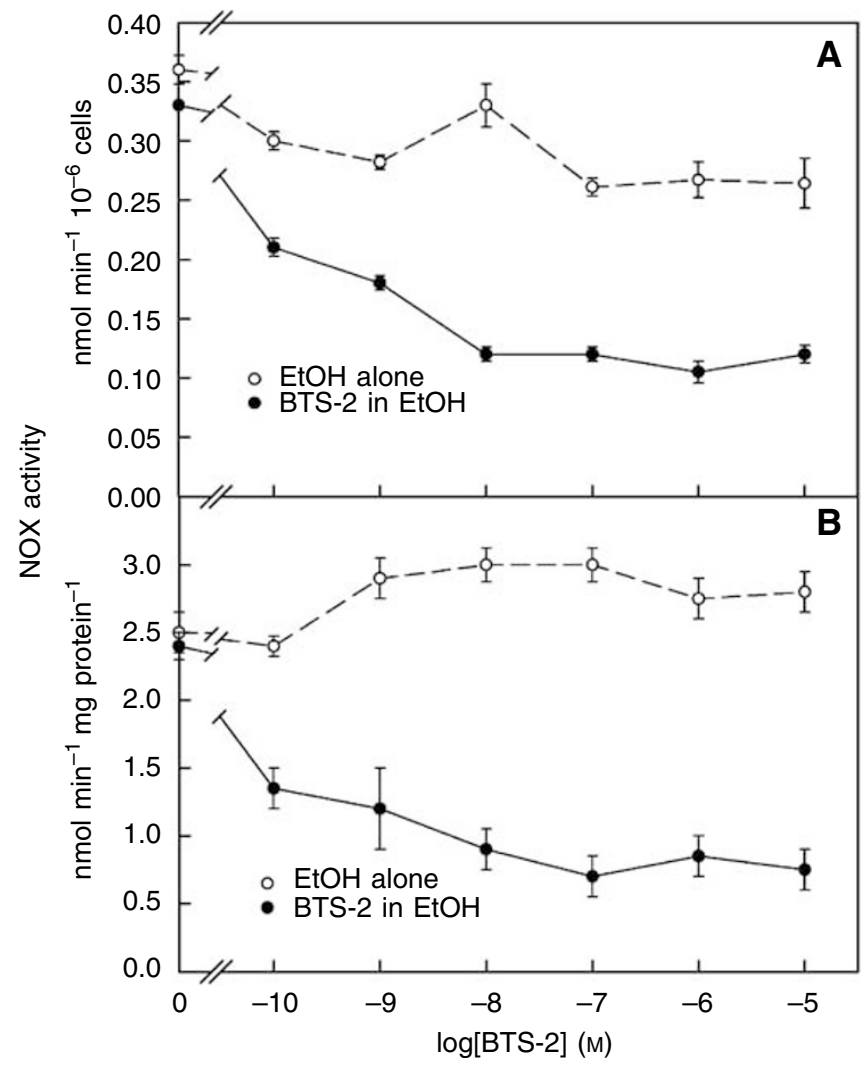

Figure 3 Dose-dependent inhibition by BTS-2 of NOX activity of $(\mathbf{A})$ HeLa cells and (B) Cellex preparations in the presence of $100 \mathrm{~mm} \mathrm{GSH}$ (solid symbols). Assay was based on spectrophotometric measurement of $\mathrm{NADH}$ disappearance at $340 \mathrm{~nm}$. The compound was dissolved in ethanol and compared to solvent alone (open symbols). 
(Minneapolis, USA), which is a mixture of NOXs (Del CastilloOlivares et al, 1998), or from intact HeLa cells. NADH is an impermeant substrate and, therefore, can be used to measure cell surface NADH activity with whole cells. Results with isolated plasma membrane and with whole cells were similar. $\mathrm{NADH}$ oxidase activity was determined as the disappearance of NADH measured at $340 \mathrm{~nm}$. The compound was dissolved in ethanol and compared to solvent alone. As shown in Figure 3, in the presence of reducing conditions, that is, $100 \mu \mathrm{M} \mathrm{GSH}$, the drug inhibited strongly the NOX activity of both the intact $\mathrm{HeLa}$ (Figure $3 \mathrm{~A}$ ) and Cellex (Figure $3 \mathrm{~B}$ ) preparations with an $\mathrm{EC}_{50}$ of about $0.1 \mathrm{~nm}$. The figure also shows small stimulations by ethanol (chemical hormesis) that are not unusual for the cell surface NOX activities (Morré, 2000). Although both the Cellex and intact $\mathrm{HeLa}$ preparations contain a cancer-specific and druginhibited tNOX and a constitutive and drug-resistant NOX, the data show that only tNOX is being inhibited, and indicate that this inhibition, which is dose dependent, is almost complete at $0.1 \mu \mathrm{M}$. Otherwise, the residual NOX activity corresponding to CNOX would approach zero at the high drug concentration. In agreement with this, NOX activities of plasma membranes purified from soybean (Glycine max), which contain only CNOX, were unaffected by BTS-2 over the concentration range $10^{-11}-10^{-5} \mathrm{M}$ $(N=4)$ (not shown).

The effect of the drug on the NOX activity under oxidising conditions is analysed in Figure 4. As can be seen, when the oxidising conditions were provided by treatment of HeLa cells with hydrogen peroxide (Figure 4A), the derivative inhibited only at the highest concentration of $10 \mu \mathrm{m}$. Moreover, with Cellex preparations (Figure 4B), stimulation was recorded at $10 \mu \mathrm{M}$. As with hydrogen peroxide, when the assays were performed in the presence of $100 \mu \mathrm{M}$ GSSG (Figure 4C and D), we could see no inhibition of the NOX activity, only a slight stimulation. Thus, it can be concluded that while under reducing conditions BTS-2 strongly inhibits tNOX, under oxidising conditions there is no effect of the drug or just a slight stimulation of activity. The absolute dependency of inhibition on redox state of tNOX has also been described with the antitumour sulphonylureas (Morré et al, 1998).

\section{DISCUSSION}

We have previously shown that BTS derivatives are strong cytotoxic agents that induce ROS overproduction and apoptosis

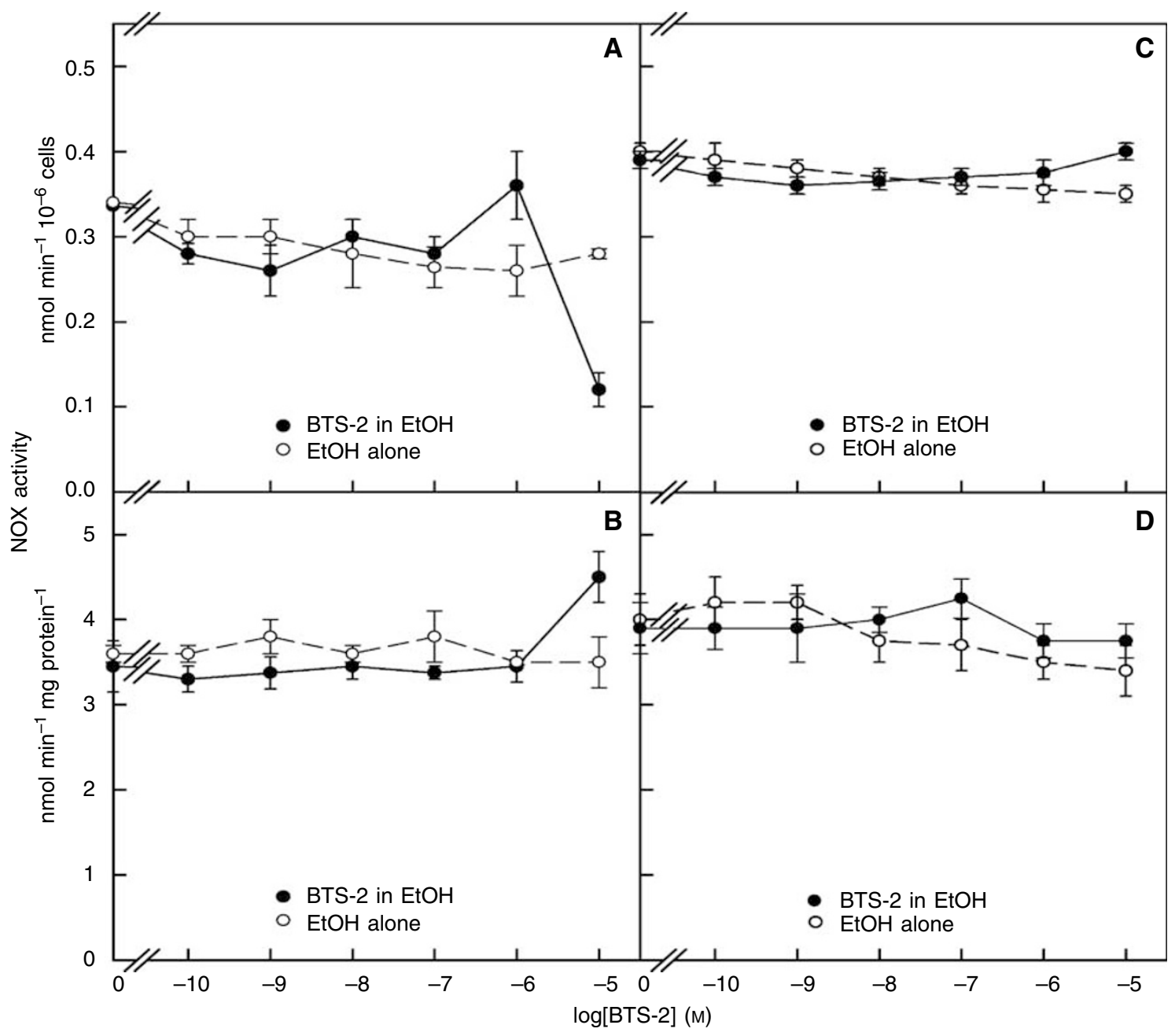

Figure 4 Lack of inhibition of the NOX activity by BTS-2 under oxidising conditions (solid symbols). (A) Normal NOX assays performed with intact HeLa cells in which the preparations were first reduced with $100 \mathrm{mM}$ GSH for 10 min and then fully oxidised by addition of $0.03 \%$ hydrogen peroxide for $10 \mathrm{~min}$. (B) As in (A) but with $50 \mathrm{ml}$ of the Cellex preparation. (C) As in (A) but with assay in the presence of $100 \mathrm{~mm}$ GSSG. (D) As in (B) but with assay in the presence of $100 \mathrm{~mm}$ GSSG. The compounds were dissolved in ethanol and compared to solvent alone (open symbols). The ethanol concentration was $0.16 \%$ maximum. 
in tumour cells (Alonso et al, 2003). We have also shown that while the BTS derivatives that exhibit this cytotoxic activity are able to inhibit a NOX activity of the plasma membrane of leukaemia CCRF-CEM cells, those that lack cytotoxic activity also lack this inhibitory effect (Alonso et al, 2001), thus suggesting that ECTONOX proteins could provide a molecular target for the induction of ROS production by BTS derivatives. Here we report that BTS-2, a new BTS derivative with high lipophilicity and improved cytotoxic activity, specifically inhibits the tNOX activity of HeLa cells, and we show that this inhibition is dependent on the redox state of tNOX.

A number of motifs within tNOX, including an NADH binding site, a quinone binding site and sites for protein disulphide-thiol interchange, account for the range of its functional activities (Chueh et al, 2002b). The drug response of tNOX has been studied extensively with LY181984 (Morré et al, 1998). Activity is inhibited or stimulated by this sulphonylurea depending on the redox environment of the protein. Ubiquinone competes with both LY181984 binding and inhibition of enzymatic activities and so the drug, like capsaicin (Morré et al, 1995c), EGCg (Morré et al, 2000) and adriamycin (Morré et al, 1997c), which also inhibit activity, is considered to occupy the quinone binding site. Interestingly, while the normal CNOX isoform and tNOX share functional characteristics, CNOX appears to lack the quinone binding motif EEMTE (Chueh et al, 2002a), a fact that could explain why both enzymes differ primarily in their sensitivity to these drugs. Since we show here that under reducing conditions BTS-2 inhibits strongly the NOX activity of both intact HeLa cells and Cellex preparations containing both tNOX and CNOX, while ECTO-NOX activities of plasma membranes from soybean, which contain only CNOX, are unaffected by this drug, the possibility that BTS derivatives exert their specific inhibitory action on tNOX activity through binding to the quinone site should be considered.

It has been described that the tNOX activity can be inhibited by thiol reagents such as the $N$-ethyl-maleimide (NEM) (Morre et al, $1995 \mathrm{a}, \mathrm{b})$. It has also been reported that compounds carrying the benzo[b]thiophene 1,1-dioxide nucleus, like BTS-1 and -2, are thiol reagents (Bordwell et al, 1954). For this reason, it is very interesting that the $\mathrm{C} 2-\mathrm{C} 3$ dihydro derivative of BTS-1, which was reported to be inactive both in the cytotoxicity and enzymatic assays (Alonso et al, 2001), cannot be considered a thiol reagent. Since this compound and BTS-1 have identical molecular sizes and capacities to interact through polar groups, hydrogen bonds and/ or hydrophobic interactions with putative receptor sites, activity of BTS- 1 can be attributed to the $\mathrm{C} 2-\mathrm{C} 3$ double bond reactivity. In agreement with this, the C3-methyl derivative of BTS-1 shows no cytotoxic activity (Villar et al, 2004), a result that can be attributed to its impaired reactivity towards thiol groups. Thus, the possibility that BTS derivatives exert their inhibitory action on tNOX activity by interacting with cysteines of the active sites for protein disulphide-thiol interchange should also be considered. The fact that BTS actions over cell growth are prevented by previous treatment of the cells with $\mathrm{N}$-acetyl-cysteine (Alonso et al, 2003) and our finding that under oxidising conditions there is no effect of BTS-2 on the tNOX activity also support this idea.

Interference with DNA and RNA is generally considered to account for the cytotoxicity of anthracycline antitumour drugs. However, it has been shown that doxorubicin is cytotoxic even without entering the cells (Tritton and Yee, 1982), and inhibition of tNOX activity by doxorubicin $\left(\mathrm{EC}_{50}=0.7 \mathrm{nM}\right)$ has been described (Morré et al, 1997c; Hedges et al, 2003). Interestingly, when cell growth is inhibited, redox activities of the plasma membrane are also inhibited, and thus NOX activity of the plasma membrane has been suggested as a growth-related doxorubicin target at the surface of cancer cells (Kim et al, 2002; Hedges et al, 2003). For this reason, the fact that BTS- 2 acts in the same order of magnitude as doxorubicin against K-562 tumour cells and also against normal HLFs that should have a low or even absent tNOX activity rises the possibility of additional sites of action for this drug. Further experiments are required to clarify this fact.

\section{ACKNOWLEDGEMENTS}

RV was the recipient of a fellowship from the Departamento de Educación y Cultura, Gobierno de Navarra.

\section{REFERENCES}

Ahmad N, Adhami VM, Gupta S, Cheng P, Mukhtar H (2002) Role of the retinoblastoma (pRb)-E2F/DP pathway in cancer chemopreventive effects of green tea polyphenol epigallocatechin-3-gallate. Arch Biochem Biophys 398: $125-131$

Ahmad N, Feyes DK, Nieminen AL, Agarwal R, Mukhtar H (1997) Green tea constituent epigallocatechin-3-gallate and induction of apoptosis and cell cycle arrest in human carcinoma cells. J Natl Cancer Inst 89: 1881 - 1886

Ahmad N, Gupta S, Mukhtar H (2000) Green tea polyphenol epigallocatechin-3-gallate differentially modulates nuclear factor kappaB in cancer cells versus normal cells. Arch Biochem Biophys 376: 338-346

Alonso MM, Asumendi A, Villar J, Gil MJ, Martínez-Merino V, Encío I Migliaccio M (2003) New benzo(b)thiophenesulphonamide 1,1-dioxide derivatives induce a reactive oxygen species-mediated process of apoptosis in tumor cells. Oncogene 22: 3759-3769

Alonso MM, Encío I, Martínez-Merino V, Gil MJ, Migliaccio M (2001) New cytotoxic benzo $(b)$ thiophenilsulfonamide 1,1-dioxide derivatives inhibit a $\mathrm{NADH}$ oxidase located in plasma membranes of tumor cells. Br J Cancer 85: $1400-1402$

Bordwell FG, Chapman RD, McKellin WH (1954) Benzothiophen chemistry. VI. A peroxide effect in the addition of thiophenols to benzothiophene 1-dioxide. J Am Chem Soc 76: 3637-3639

Challenger F, Clapham PH (1948) Some derivatives of thionaphthen. J Chem Soc (oct): 1615-1618

Chern MK, Wu TC, Hsieh CH, Chou CC, Liu LF, Kuan IC, Yeh YH, Hsiao CD, Ming F, Tam MF (2000) Tyr115, gln165 and trp209 contribute to the 1, 2-epoxy-3-( $p$-nitrophenoxy)propane-conjugating activity of glutathione S-transferase cGSTM1-1. J Mol Biol 300: 1257-1269
Chueh PJ, Kim C, Cho N, Morré DM, Morré DJ (2002a) Molecular cloning and characterization of a tumor-associated, growth-related, and timekeeping hydroquinone (NADH) oxidase (tNOX) of the HeLa cell surface. Biochemistry 41: $3732-3741$

Chueh PJ, Morré DM, Morré DJ (2002b) A site-directed mutagenesis analysis of tNOX functional domains. Biochim Biophys Acta 1594: 74-83

Del Castillo-Olivares A, Yantiri F, Chueh PJ, Wang S, Sweeting M, Sedlak D, Morré DM, Burgess J, Morré DJ (1998) A drug-responsive and proteaseresistant peripheral NADH oxidase complex from the surface of HeLa S cells. Arch Biochem Biophys 358: 125-140

Gil MJ, Mañú M, Arteaga C, Migliaccio M, Encío IJ, González A, MartínezMerino V (1999) Synthesis and cytotoxic activity of $N$-(2-pyridylsulfenyl)urea derivatives. A new class of potential antineoplastic agents. Bioorg Med Chem Lett 9: 2321-2324

Gupta S, Ahmad N, Nieminen AL, Mukhtar H (2000) Growth inhibition, cell-cycle dysregulation, and induction of apoptosis by green tea constituent (-)-epigallocatechin-3-gallate in androgen-sensitive and androgen-insensitive human prostate carcinoma cells. Toxicol Appl Pharmacol 164: 82 -90

Hedges KL, Morré DM, Wub LY, Morré DJ (2003) Adriamycin tolerance in human mesothelioma lines and cell surface NADH oxidase. Life Sci 73: $1189-1198$

Karplus PA, Schulz GE (1989) Substrate binding and catalysis by glutathione reductase as derived from refined enzyme: substrate crystal structures at $2 \AA$ resolution. J Mol Biol 210: $163-180$

Kim C, Crane FL, Faulk WP, Morré DJ (2002) Purification and characterization of a doxorubicin-inhibited NADH-quinone 
(NADH-ferricyanide) reductase from rat liver plasma membranes. $J$ Biol Chem 277: 16441 - 16447

Martínez-Merino V, Gil MJ, Encío I, Migliaccio M, Arteaga C (2000) Benzo $[b]$ thiophene sulfonamide-1,1-dioxido derivatives and their use as antineoplastic agents. WO Patent 00/63202

Martínez-Merino V, Martínez-González A, González A, Gil MJ (1995) 3DQSAR of the diarylsulphonylureas as antineoplastic agents. In QSAR and Molecular Modelling: Concepts, Computational Tools and Biological Applications Sanz F, Giraldo J, Manaut F (eds) pp 478-480. Barcelona: Prous Science Publishers

Meerwein H, Dittmer G, Gollner R (1957) Verfahren zur herstellung aromatischer sulfonsäurechloride, eine neue modifikation der Sandmeyerschen reaktion. Chem Ver 90: $841-1178$

Morré DJ, Wu LY, Morré DM (1995b) The antitumor sulfonylurea $\mathrm{N}$-(4methylphenylsulfonyl)- $N^{\prime}$-(4-chlorophenyl) urea (LY181984) inhibits NADH oxidase activity of HeLa plasma membranes. Biochim Biophys Acta 1240: $11-17$

Morré DJ (2000) Chemical hormesis in cell growth: a molecular target at the cell surface. J Appl Toxicol 20: $157-163$

Morré DJ, Bridge A, Wu LY, Morré DM (2000) Preferential inhibition by (-)-epigallocatechin-3-gallate of the cell surface NADH oxidase and growth of transformed cells in culture. Biochem Pharmacol 60: $937-946$

Morré DJ, Caldwell S, Mayorga A, Wu LY, Morré DM (1997a) $\mathrm{NADH}$ oxidase activity from sera altered by capsaicin is widely distributed among cancer patients. Arch Biochem Biophys 342: $224-230$

Morré DJ, Chueh PJ, Morré DM (1995c) Capsaicin inhibits preferentially the NADH oxidase and growth of transformed cells in culture. Proc Natl Acad Sci USA 92: 1831 - 1835

Morré DJ, Kim C, Paulik M, Morré DM, Faulk WP (1997c) Is the drug-responsive $\mathrm{NADH}$ oxidase of the cancer cell plasma membrane a molecular target for adriamycin. J Bioenerg Biomembr 29: $269-280$
Morré DJ, Morré DM (2003) Cell surface NADH oxidases (ECTO-NOX proteins) with roles in cancer, cellular time-keeping, growth, aging and neurodegenerative diseases. Free Radic Res 37: 795-808

Morré DJ, Morré DM, Stevenson J, Mackellar W, McClure D (1995a) HeLa plasma membranes bind the antitumor sulfonylurea LY181984 with high affinity. Biochim Biophys Acta 1244: 133-140

Morré DJ, Reust T (1997b) A circulating form of NADH oxidase activity responsive to the antitumor sulfonylurea $\mathrm{N}$-4-(methylphenylsulfonyl)$N^{\prime}$-(4-chlorophenyl)urea (LY181984) specific to sera from cancer patients. J Bioenerg Biomembr 29: $281-289$

Morré DJ, Wu LY, Morré DM (1998) Response of a cell-surface NADH oxidase to the antitumor sulfonylurea $N$-(4-methylphenylsulfonyl)- $N^{\prime}$-(4chlorophenylurea) (LY181984) modulated by redox. Biochim Biophys Acta 1369: 185 - 192

Mosmann T (1983) Rapid colorimetric assay for cellular growth and survival: application to proliferation and cytotoxicity assays. J Immunol Methods 65: $55-59$

Salucci M, Stivala LA, Maiani G, Bugianesi R, Vannini V (2002) Flavonoids uptake and their effect on cell cycle of human colon adenocarcinoma cells (Caco2). Br J Cancer 86: 1645-1651

Sedlak D, Morré DM, Morré DJ (2001) A drug-unresponsive and proteaseresistant CNOX protein from human sera. Arch Biochem Biophys 386: $106-116$

Smith PK, Krohn RI, Hermanson GT, Mallia AK, Gartner FH, Provenzano MD, Fujimoto EK, Goeke NM, Olson BJ, Klenk DC (1985) Measurement of protein using bicinchoninic acid. Anal Biochem 150: 76-85

Tritton RR, Yee G (1982) The anticancer agent adriamycin can be actively cytotoxic without entering cells. Science 217: $248-250$

Villar R, Encío I, Migliaccio M, Gil MJ, Martínez-Merino V (2004) Synthesis and cytotoxic activity of lipophilic sulphonamide derivatives of the benzo[b]thiophene 1,1-dioxide. Bioorg Med Chem 12: $963-968$

Wang S, Morré DM, Morré DJ (2003) Sera from cancer patients contain two oscillating ECTO-NOX activities with different period lengths. Cancer Lett 190: $135-141$ 